\section{Chemical and Sensory Properties of Greenhouse Tomatoes Remain Unchanged in Response to Red, Blue, and Far Red Supplemental Light from Light-emitting Diodes}

\author{
Michael P. Dzakovich ${ }^{\mathbf{a}}$ and Celina Gómez \\ Department of Horticulture and Landscape Architecture, Purdue University, \\ 625 Agriculture Mall Drive, West Lafayette, IN 47907-2010
}

\author{
Mario G. Ferruzzi \\ Department of Food Science, Purdue University, 745 Agriculture Mall Drive, \\ West Lafayette, IN 47907-2010
}

Cary A. Mitchell

Department of Horticulture and Landscape Architecture, Purdue University, 625 Agriculture Mall Drive, West Lafayette, IN 47907-2010

Additional index words. carotenoids, flavonoids, photobiology, Solanum lycopersicum, flavor, hydroponics

\begin{abstract}
In addition to photosynthesis, light is a critical mediator of secondary metabolism in plants, signaling the production of potentially health-promoting phytochemicals and regulating the emission of volatile organic compounds (VOCs) that can alter the sensory perception of a tomato. Light-emitting diodes (LEDs) are a viable way to test the effects of individual wavebands of light and are being quickly adopted by the greenhouse tomato industry. However, studies characterizing the effects of specific wavelengths of light or supplemental lighting on phytochemical content in general are lacking. We hypothesized that enriching the amount of supplemental blue and/or red light that tomatoes receive would positively affect the amount of carotenoids and phenolic compounds that accumulate in tomato fruits through cryptochrome and/or phytochrome-dependent signaling pathways. To test this hypothesis, we compared the chemical and sensory characteristics of tomatoes grown with overhead high-pressure sodium (OH-HPS) lamps to those grown with intracanopy (IC)-LEDs emitting different ratios of red, blue, and far red light. Tomatoes were profiled for total soluble solids, titratable acidity, ascorbic acid content, $\mathrm{pH}$, total phenolics, and prominent flavonoids and carotenoids. Our studies indicated that greenhouse tomato fruit quality was only marginally affected by supplemental light treatments. Moreover, consumer sensory panel data indicated that tomatoes grown under different lighting treatments were comparable across the lighting treatments tested. Our research suggests that the dynamic light environment inherent to greenhouse production systems may nullify the effects of wavelengths of light used in our studies on specific aspects of fruit secondary metabolism.
\end{abstract}

Plants are sessile organisms that use numerous mechanisms to respond to dynamic environmental factors. One such factor is light, which is a powerful elicitor of primary and secondary metabolism that ultimately

Received for publication 6 Sept. 2017. Accepted for publication 9 Nov. 2017.

Funding was from the USDA NIFA-SCRI program (2010-51181-21369).

We thank Judy Santini for statistical consulting, as well as Sydney Moser and Ben Redan for guidance in the quantification of flavonols. We also thank Rob Eddy, Dan Hahn, Eric Whitehead, Dan Martin, Roger Rozzi, and Joe Littiken for their help in greenhouse studies.

${ }^{1}$ Corresponding author. E-mail: michaelpdz@, gmail.com.
LEDs are gaining popularity not only because of their gradually increasing energy efficiency but also because of their long life span, relatively cool emitting surfaces, and ability to emit narrow-waveband light (Morrow, 2008; Nelson and Bugbee, 2014). Different qualities and quantities of light can influence not only growth and development but also secondary metabolic processes that determine nutritive value and flavor attributes. This research spans many high-value crops including arugula (Eruca sativa) (Mattson and Harwood, 2012), broccoli microgreens (Brassica oleracea) (Kopsell and Sams, 2013), cabbage (Mizuno et al., 2011), lettuce (Lactuca sativa) (Li and Kubota, 2009; Stutte et al., 2009), kale (Carvalho and Folta, 2014b; Lefsrud et al., 2008), and tomato (Gautier et al., 2005b) among many others. Further examples of light influencing produce quality have been well reviewed (Carvalho and Folta, 2014a; Mitchell et al., 2015). The effects seen in these studies are frequently related to changes in ascorbic acid, carotenoids, and polyphenolic compounds.

Ascorbic acid (vitamin C) is a cofactor for many metabolic processes, serves as an antioxidant, and is an essential nutrient for humans (Laing et al., 2007). Ascorbic acid accumulation in tomatoes has been shown to be a function of fruit irradiance, creating the possibility to use intracanopy lighting (ICL) with LEDs to increase concentrations in tomato fruits (Gautier et al., 2009). Tomatoes also contain bioactive flavonoids such as quercetin-3-O-rutinoside (rutin) and kaempferol-3-O-rutinoside that have been associated with several positive health benefits (González et al., 2011; Kauss et al., 2008; Naderi et al., 2003; Raiola et al., 2014; Spencer, 2009). The biosynthesis of these compounds can also be modulated in response to light (Jagadeesh et al., 2009; Li and Kubota, 2009; Ordidge et al., 2010; Stutte et al., 2009). Last, tomatoes are an excellent source of carotenoids, most notably lycopene, which are associated with reduced risk for cardiovascular disease and some cancers (Ciccone et al., 2013; GonzálezVallinas et al., 2013). Blue, red, and far red light have been shown to alter tomato fruit concentrations of both lycopene and $\beta$-carotene (Alba et al., 2000; Gautier et al., 2011, 2008). Manipulating flavonoids and carotenoids in tomato fruits could also indirectly alter the concentrations of VOCs that are produced from these same pathways (Baldwin et al., 1991; Tieman et al., 2006). However, limited studies exist relating light quality to tomato fruit composition and sensory properties.

We hypothesized that direct irradiation of tomato fruit clusters with supplemental light would alter the concentrations of ascorbic acid, carotenoids, and polyphenolic compounds depending on the quality of light used. To test these hypotheses, we supplemented greenhouse tomatoes grown using commercial practices with different qualities of light from HPS fixtures or custom-built IC-LED towers. One variety was also grown 
outdoors to establish a "garden-grown" quality benchmark in Expt. 1. Tomatoes were then tested using several physicochemical quality metrics including total soluble solids, citric/ascorbic acid content, $\mathrm{pH}$, total phenolics, and prominent flavonoids and carotenoids. We also included a consumer sensory panel in Expt. 2 to gauge how ratios of red, blue, and far red light affect the sensory attributes of greenhouse-grown tomatoes.

\section{Materials and Methods}

Plant materials and growing conditions. For Expt. 1, 'Komeett' tomato seeds (De Ruiter Seeds, Columbus, $\mathrm{OH}$ ) were sown into Agrifoam soilless plug strips (SteadyGROWpro; Syndicate Sales, Kokomo, IN) in late Spring 2014 in a glass-glazed greenhouse located in West Lafayette, IN (lat. $40^{\circ} \mathrm{N}$, long. $86^{\circ} \mathrm{W}$; USDA hardiness zone $5 \mathrm{~b}$ ). Fertigation was carried out on an as-needed basis using an acidified fertilizer solution that contained a $3: 1$ mixture of $15 \mathrm{~N}-2.2 \mathrm{P}-12.5 \mathrm{~K}$ and $21 \mathrm{~N}-2.2 \mathrm{P}-16.6 \mathrm{~K}$, respectively, providing $200 \mathrm{~N}-\mathrm{NO} 3,26 \mathrm{P}, 163 \mathrm{~K}, 50 \mathrm{Ca}, 20 \mathrm{Mg}$, and micronutrients $\left(\mathrm{mg} \cdot \mathrm{L}^{-1}\right.$; The Scotts Co., Marysville, $\mathrm{OH})$. Plants were transferred into rooting blocks (SteadyGROWpro; Syndicate Sales) and placed onto wetted coconut coir slabs (Riococo 200; Ceyhinz Link International, Inc., Dallas/Fort Worth, TX). Slabs were placed onto steel gutters $(9.8 \mathrm{~m} \times 25 \mathrm{~cm}$; FormFlex Horticultural Systems, Ontario, Canada), aligned east-west, and plant density was 2.2 stems $/ \mathrm{m}^{2}$. Plants were irrigated using a commercially standard fertilizer mix (4.5N-14P-34K; CropKing, Lodi, $\mathrm{OH})$ and irrigation frequency was adjusted as needed to maintain a daily leaching fraction (LF) of $30 \%$ (4.5N-14P-34K; CropKing). Electrical conductivity (EC) and $\mathrm{pH}$ of the influx and efflux were tested each day using a hand-held $\mathrm{EC}$ and $\mathrm{pH}$ meter (Hanna Instruments, Woonsocket, RI) and fertigation adjusted as needed to ensure that values were maintained within recommended ranges $\left(2.5-3.5 \mathrm{dS} \cdot \mathrm{m}^{-1}\right.$ and 5.8-6.3 for $\mathrm{EC}$ and $\mathrm{pH}$, respectively) (Jones, 2008). Average day/night greenhouse temperatures were set to $25 / 15{ }^{\circ} \mathrm{C}$, respectively. Plants were trellised on a high-wire system, and the experiment was conducted between July and Nov. 2014. To establish a "garden-grown" control, 'Komeett' plants were also grown in an outdoor field site. Seedlings were cultured similarly as described previously but transferred to a field site with cambric-loam soil previously amended with organic compost after 5 weeks of growth in late Spring 2014. Plants were staked using the 'Florida Weave' method and weeds were suppressed using heavy-duty weed cloth (FarmTek, Dyersville, IA).

For Expt. 2, 'Merlice' (De Ruiter Seeds) tomato plants were cultured similarly to plants in Expt. 1 except that they were started in early Dec. 2014, grafted onto 'Maxifort' (De Ruiter Seeds) rootstocks, pruned to have two leading heads per plant, the steel gutters were arranged facing north-south, and the experiment lasted $\approx 5$ months.
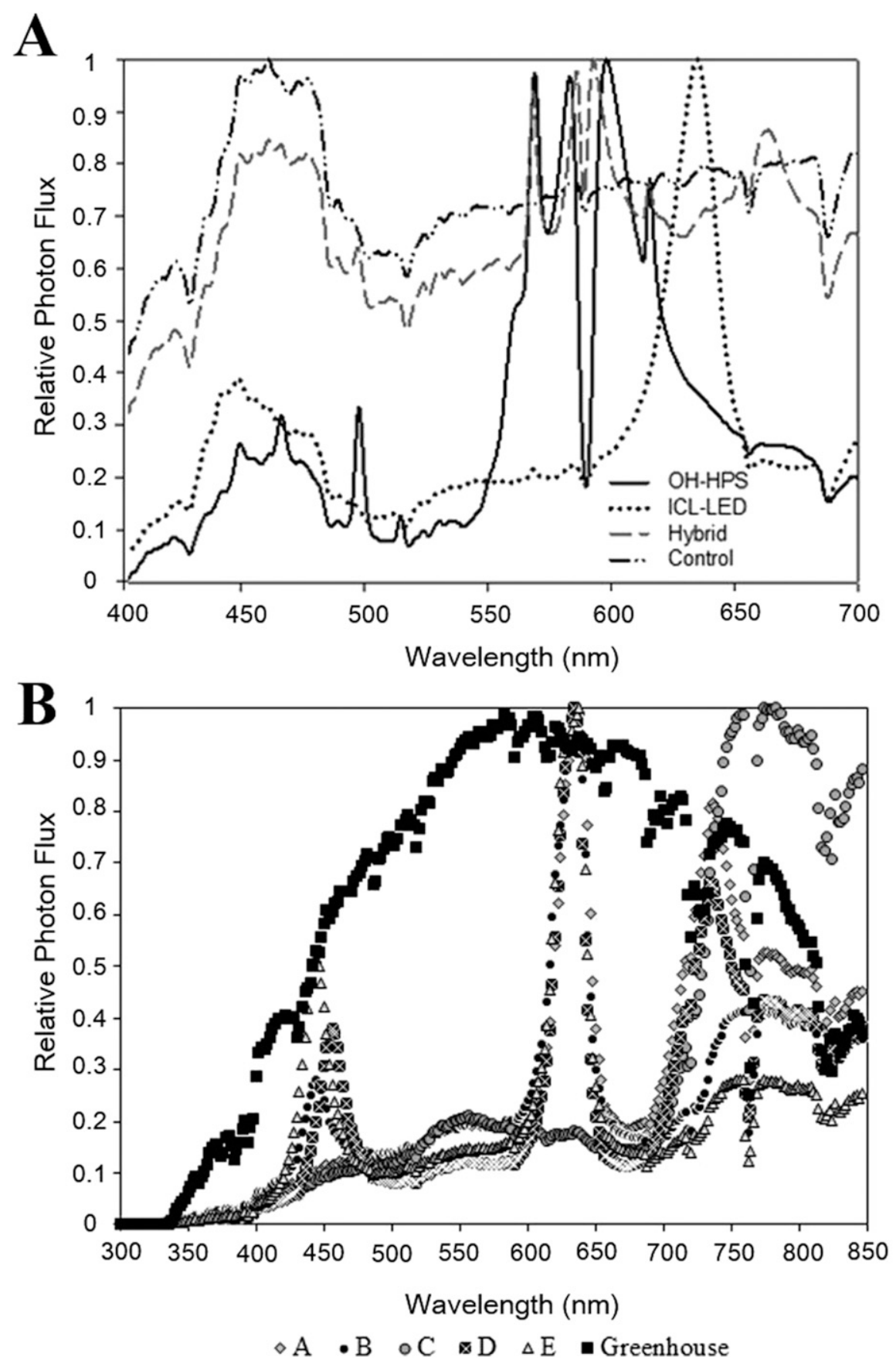

Fig. 1. Treatment-specific spectra (solar + supplemental lighting) averaged across three leaf layers within a high-wire tomato canopy for Expt. 1 (A) and Expt. 2 (B). Treatments included overhead highpressure sodium (OH-HPS) lamps; intracanopy light-emitting diodes (ICL-LED); hybrid supplemental lighting (OH-HPS + ICL-LED); or unsupplemented controls. For Expt. 2, treatments were A: 0\% blue, $80 \%$ red, and $20 \%$ far red; B: $10 \%$ blue, $90 \%$ red, and $0 \%$ far red; C: unsupplemented control; D: $25 \%$ blue, $60 \%$ red, and $15 \%$ far red; and E: $30 \%$ blue, $70 \%$ red, and $0 \%$ far red. Measurements were taken between 1200 and 1300 HR on a sunny day.

Lighting treatments. For Expt. 1, the greenhouse was divided into three blocks using movable double-layered 6-mil (150 $\mathrm{mm}$ ) white polyethylene plastic curtains that were $3.6 \mathrm{~m}$ in height (Supplemental Table 1; Supplemental Figs. 1 and 2). When supplemental lighting was inactive, the curtains were withdrawn to allow for maximum transmission of solar photosynthetically active radiation $(P A R)$ into crop canopies. Each block was divided into four $1.8 \times 2.4-\mathrm{m}$ sections allowing for four different treatments to be represented in each block. Each section was divided by a piece of white polyethylene large enough to reduce light pollution between treatments within a block but not to inhibit airflow within the greenhouse. Eight double-headed plants were grown within each supplemental lighting treatment.

In Expt. 1, supplemental light treatments provided a fluence rate of $180 \mu \mathrm{mol} \cdot \mathrm{m}^{-2} \cdot \mathrm{s}^{-1}$ 
Table 1. Basic physicochemical fruit content attributes as influenced by supplemental light treatment or outdoor environmental conditions.

\begin{tabular}{|c|c|c|c|c|c|}
\hline Treatment & Sample size & Brix $^{2}$ & $\mathrm{pH}$ & Titratable acidity $\left(\mathrm{g} \cdot \mathrm{L}^{-1}\right)$ & Sugar/acid \\
\hline \multicolumn{6}{|l|}{ Expt. 1} \\
\hline OH-HPS & $n=9$ & $3.52 \pm 0.16 \mathrm{a}^{\mathrm{x}}$ & $4.12 \pm 0.02 \mathrm{a}^{\mathrm{x}}$ & $4.01 \pm 0.95 \mathrm{a}^{\mathrm{x}}$ & $8.76 \pm 0.26 \mathrm{a}$ \\
\hline Hybrid & $n=9$ & $3.56 \pm 0.09 \mathrm{a}^{\mathrm{x}}$ & $4.11 \pm 0.01 \mathrm{a}^{\mathrm{x}}$ & $4.47 \pm 0.17 \mathrm{a}$ & $8.0 \pm 0.15 \mathrm{a}^{\mathrm{x}}$ \\
\hline Outdoor & $n=3$ & $4.17 \pm 0.03$ & $4.2 \pm 0$ & $4.4 \pm 0.86 \mathrm{a}$ & $9.47 \pm 0.02$ \\
\hline \multicolumn{6}{|l|}{ Expt. 2} \\
\hline A & $n=6$ & $3.82 \pm 0.15 \mathrm{a}$ & $4.1 \pm 0 \mathrm{a}$ & $4.95 \pm 0.05 \mathrm{a}$ & $7.72 \pm 0.31 \mathrm{a}$ \\
\hline D & $n=6$ & $3.83 \pm 0.12 \mathrm{a}$ & $4.15 \pm 0.02 \mathrm{a}$ & $4.97 \pm 0.16 \mathrm{a}$ & $7.76 \pm 0.4 \mathrm{a}$ \\
\hline E & $n=6$ & $3.8 \pm 0.05 \mathrm{a}$ & $4.08 \pm 0.02 \mathrm{a}$ & $4.95 \pm 0.12 \mathrm{a}$ & $7.7 \pm 0.16 \mathrm{a}$ \\
\hline
\end{tabular}

zrams sucrose/100 g sample.

${ }^{\mathrm{y}}$ Values represent means \pm standard error.

${ }^{x}$ Significantly different at $P \leq 0.05$ to outdoor controls. Values with different letters within an experiment are statistically different as determined by a Tukey's honestly significant difference test $(\alpha=0.05)$. The supplemental lighting treatments in Expt. 1 were overhead high-pressure sodium (OH-HPS) lamps; intracanopy light-emitting diodes (ICL-LED); hybrid supplemental lighting (OH-HPS + ICL-LED); or unsupplemented controls. In Expt. 2, treatments were A: $0 \%$ blue, $80 \%$ red, and $20 \%$ far red; B: $10 \%$ blue, $90 \%$ red, and $0 \%$ far red; C: unsupplemented control, D: $25 \%$ blue, $60 \%$ red, and $15 \%$ far red; and E: $30 \%$ blue, $70 \%$ red, and $0 \%$ far red.

Table 2. Absolute and hedonic ratings of select fruit attributes as influenced by light treatment in Expt. 2.

\begin{tabular}{|c|c|c|c|c|c|c|c|c|}
\hline Treatment & Sample size & Color & Aroma & Sweetness & Acidity & Aftertaste & Texture & Overall approval \\
\hline \multicolumn{9}{|l|}{$\overline{\text { Absolute }}$} \\
\hline B & $n=47$ & $6.28 \pm 0.24 \mathrm{a}$ & $5.38 \pm 0.24 \mathrm{a}$ & $4.57 \pm 0.24 \mathrm{a}$ & $5.12 \pm 0.29 \mathrm{a}$ & $5.66 \pm 0.23 \mathrm{a}$ & $5.87 \pm 0.27 \mathrm{a}$ & N/A \\
\hline $\mathrm{C}$ & $n=47$ & $6.65 \pm 0.22 \mathrm{a}$ & $5.28 \pm 0.27 \mathrm{a}$ & $4.51 \pm 0.26 \mathrm{a}$ & $5.0 \pm 0.2 \mathrm{a}$ & $5.15 \pm 0.26 \mathrm{a}$ & $5.7 \pm 0.29 \mathrm{a}$ & N/A \\
\hline $\mathrm{E}$ & $n=47$ & $6.4 \pm 0.28 \mathrm{a}$ & $5.57 \pm 0.32 \mathrm{a}$ & $4.49 \pm 0.27 \mathrm{a}$ & $5.34 \pm 0.29 \mathrm{a}$ & $5.4 \pm 0.26 \mathrm{a}$ & $5.89 \pm 0.34 \mathrm{a}$ & N/A \\
\hline \multicolumn{9}{|l|}{ Hedonic } \\
\hline A & $n=47$ & $6.96 \pm 0.22 \mathrm{a}$ & $6.36 \pm 0.24 \mathrm{a}$ & $5.23 \pm 0.27 \mathrm{a}$ & $5.4 \pm 0.29 \mathrm{a}$ & $5.87 \pm 0.25 \mathrm{a}$ & $5.77 \pm 0.31 \mathrm{a}$ & $5.89 \pm 0.23 \mathrm{a}$ \\
\hline D & $n=47$ & $6.77 \pm 0.22 \mathrm{a}$ & $5.75 \pm 0.27 \mathrm{a}$ & $5.28 \pm 0.29 a$ & $5.49 \pm 0.24 \mathrm{a}$ & $6.02 \pm 0.26 \mathrm{a}$ & $5.64 \pm 0.32 \mathrm{a}$ & $5.83 \pm 0.29 a$ \\
\hline E & $n=47$ & $6.59 \pm 0.28 \mathrm{a}$ & $5.79 \pm 0.32 \mathrm{a}$ & $5.36 \pm 0.27 \mathrm{a}$ & $5.6 \pm 0.29 \mathrm{a}$ & $5.68 \pm 0.27 \mathrm{a}$ & $5.89 \pm 0.34 \mathrm{a}$ & $5.81 \pm 0.32 \mathrm{a}$ \\
\hline
\end{tabular}

${ }^{\mathrm{z}}$ Values represent means \pm standard error.

${ }^{\mathrm{y}}$ Not applicable.

All values were statistically similar as determined by a Tukey's honestly significant difference. Values represent back-transformed means \pm SE of absolute (magnitude) and hedonic (preference) measures of select tomato fruit sensory attributes using 9-point scales. Increasing values indicate an increase in the magnitude or liking of an attribute. Test $(\alpha=0.05)$. Means represent back-transformed ratings. The supplemental lighting treatments were A: $0 \%$ blue, $80 \%$ red, and $20 \%$ far red; B: $10 \%$ blue, $90 \%$ red, and $0 \%$ far red; C: unsupplemented control; D: $25 \%$ blue, $60 \%$ red, and $15 \%$ far red; and E: $30 \%$ blue, $70 \%$ red, and $0 \%$ far red.

and a daily fluence of $10,13.8,13.8 \mathrm{~mol} \cdot \mathrm{m}^{-2} \cdot \mathrm{d}^{-1}$ for Sept., Oct., and Nov., respectively. Supplemental light treatments included 600-W OH-HPS lamps (HS2000; P.L. Lights, Beamsville, Ontario, Canada), ICL-LED towers [2.5-m tall, with three $0.60 \times 0.12-\mathrm{m}$ LED zones irradiating both directions within a row; each panel had five rows of four red and one blue (627- and 450-nm peak wavelength, respectively) LEDs; Orbital Technologies Corporation, Madison, WI], or hybrid lighting using two LED interlighting modules (2.5-m long, with one horizontal strip of 660- and 450-nm peak wavelength LEDs irradiating bidirectionally; GreenPower LED interlighting module $\mathrm{dr} / \mathrm{b}$; Philips, Eindhoven, The Netherlands) $+400-\mathrm{W}$ OH-HPS lamps (LU400ECO; Sylvania, Toronto, Ontario, Canada). Both LED lamp types provided a mix of $93 \%$ red and $7 \%$ blue. A Control treatment was included that relied only on solar PAR for plant growth and development.

In Expt. 2, five separate metal gutters (aligned North-South) spanned the greenhouse. Each gutter accommodated three custom-built LED towers (Orbitec, Madison,

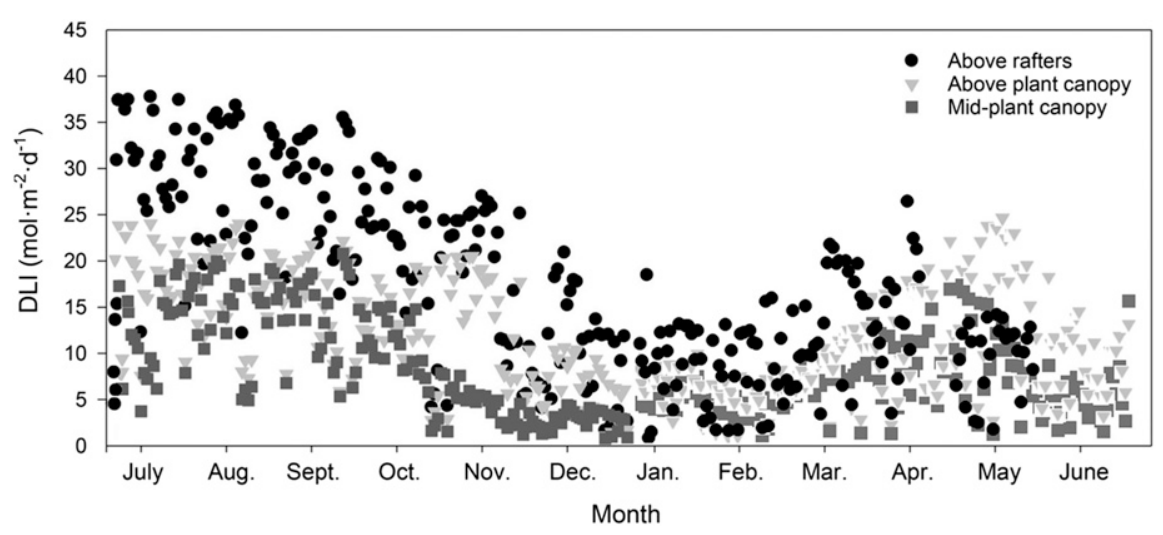

Fig. 2. Solar daily light integral (DLI) inside a glass-glazed greenhouse in West Lafayette, $\mathrm{IN}\left(40^{\circ} \mathrm{N}\right.$ latitude) from July 2014 to June 2015. Solar DLI was monitored throughout the experimental period using quantum sensors (190 SB; LI-COR Biosciences) interfaced to a data logger (CR1000; Campbell Scientific, Logan, UT). Solar DLI was monitored at three heights within the greenhouse: 1) midcanopy height in control treatments; 2) directly above top-canopy height in control treatments; and 3) above greenhouse rafters. Measurements were made every $10 \mathrm{~s}$ and data were recorded at 10 -min intervals.

WI). Treatments were separated by a piece of double-layered 6-mil $(150 \mathrm{~mm})$ white polyethylene plastic curtain that was $3.6 \mathrm{~m}$ in height (Supplemental Table 1; Supplemental
Figs. 1 and 2). Within each treatment were four individual, double-headed plants (two on each side of a tower). With five treatments total, each treatment was replicated 


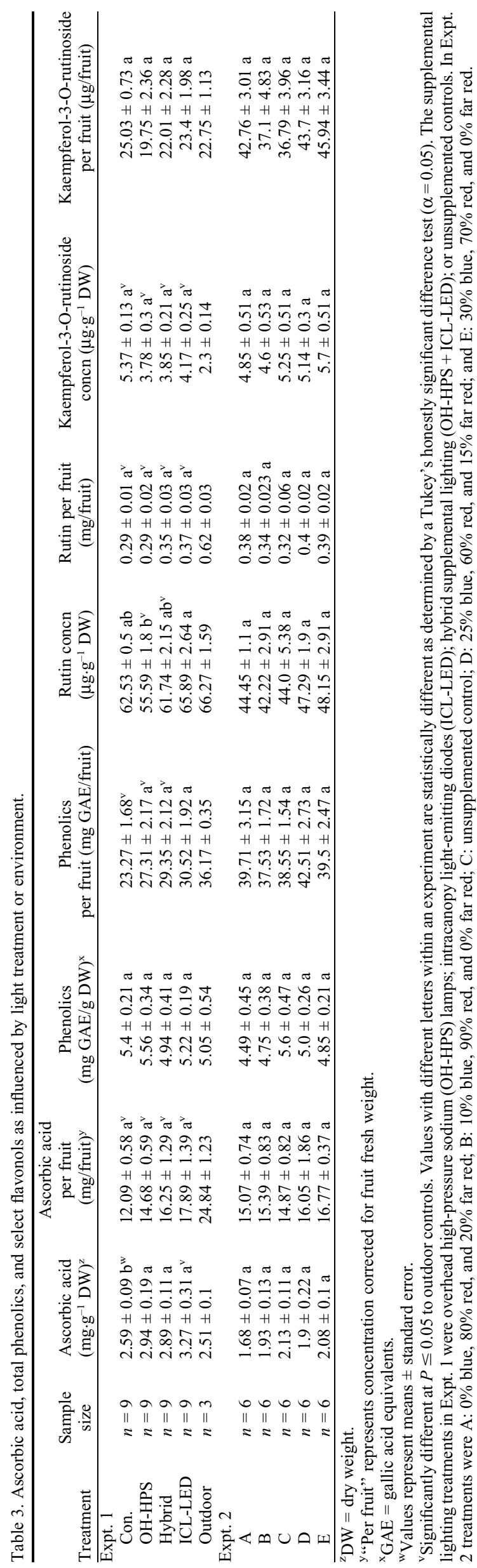

three times in the greenhouse in a randomized location. The supplemental lighting treatments were as follows: $\mathrm{A}-0 \%$ blue, $80 \%$ red, and $20 \%$ far red (peak wavelengths: 640 and $730 \mathrm{~nm}$ ); B-10\% blue, $90 \%$ red, and $0 \%$ far red (peak wavelengths: 444 and $642 \mathrm{~nm}$ ); C-unsupplemented control with an unlit tower installed to mimic any potential shading effects of the LED lighting systems; D- $25 \%$ blue, $60 \%$ red, and $15 \%$ far red (peak wavelengths: 456,636 , and $730 \mathrm{~nm}$ ); E-30\% blue, $70 \%$ red, and $0 \%$ far red (peak wavelengths: 442 and $638 \mathrm{~nm}$ ). Before the beginning of the experiment, all LED towers were calibrated to emit $180-\mu \mathrm{mol} \cdot \mathrm{m}^{-2} \cdot \mathrm{s}^{-1}$ within plant canopies and were run for $16 \mathrm{~h} \cdot \mathrm{d}^{-1}$ for a total fluence of $10.4 \mathrm{~mol} \cdot \mathrm{m}^{-2} \cdot \mathrm{d}^{-1}$. Light intensity was measured with a spherical quantum sensor (LI-250A; LI-COR Biosciences, Lincoln, NE) calibrated against a spectroradiometer (EPP-2000; StellarNet, Inc., Tampa, FL). Relative photon flux for Expts. 1 and 2 can be seen in Fig. 1.

Chemical reagents. Kaempferol-3O-rutinoside and quercetin-3-O-rutinoside standards were obtained from ChromaDex (ChromaDex, Irvine, CA). Metaphosphoric acid crystals were purchased from Flinn Scientific (Flinn Scientific, Inc., Batavia, IL). Acetic acid $(\geq 99 \%)$, ascorbic acid ( $\geq 99 \%$ ), 2,6-dichloroindophenol $(\geq 97 \%)$, Folin-Ciocalteu phenol reagent $(2 \mathrm{~N})$, formic acid ( $\geq 95 \%)$, gallic acid ( $97.5 \%$ to $102.5 \%)$, $0.1 \mathrm{~N}$ sodium hydroxide solution, sodium bicarbonate $(\geq 99.5 \%)$, and sodium carbonate $(\geq 99.5)$ were purchased from SigmaAldrich (Sigma-Aldrich Co., St. Louis, MO). Acetone ( $\geq 99.5 \%)$, acetonitrile (LCMS grade), ethanol (95\%), hexanes ( $\geq 95 \%)$, and water (LC-MS grade) were purchased from VWR International (Radnor, PA).

Tissue collection and basic physicochemical analyses. Stage-six tomato fruits ( $>90 \%$ of each fruit was red; USDA Tomato Ripeness Classification; 6-9 fruits/plant) were harvested and processed according to Dzakovich et al. (Dzakovich et al., 2016). Brix and titratable acidity were determined as described by Dzakovich et al. (Dzakovich et al., 2016). Ascorbic acid was determined according to Nielsen (Nielsen, 2010). Samples for the outdoor field trial, Expt. 1, and for Expt. 2 were collected over 2 weeks in late Aug. 2014 , over 2 weeks in early Oct. 2014, and over 3 weeks in late April and early May 2015, respectively. Fruit water content, fresh weight, and colorimetric information can be found in Supplemental Table 1 and Supplemental Figs. 1 and 2.

Carotenoid extraction and quantification. Carotenoids were extracted and analyzed in near darkness $\left(\leq 1 \mu \mathrm{mol} \cdot \mathrm{m}^{-2} \cdot \mathrm{s}^{-1}\right)$, using a spectrophotometer (Shimadzu UV160U; Shimadzu Corp., Kyoto, Japan) according to Nagata and Yamashita (Nagata and Yamashita, 1992). Briefly, tomato puree $(\approx 1 \mathrm{~g})$ was twice-extracted with $10 \mathrm{~mL}$ of 2:3 acetone:hexanes. Carotenoid tissue concentration was expressed on a dry weight basis after correcting for sample water content. 
Total phenolics. Phenolic compounds were extracted from lyophilized tomato tissue using the method of Luthria et al. (Luthria et al., 2006). To determine total phenolics, the Folin-Ciocalteu method was used according to Kulen et al. (Külen et al., 2013). A 96-well plate reader (SpectraMax 190 Microplate Reader; Molecular Devices, LLC., Sunnyvale, CA) determined the absorbance of samples at $765 \mathrm{~nm}$, and gallic acid equivalents were calculated using 5-point standard curves. All reactions were performed in triplicate.

Quantification of fruit tissue flavonols. Lyophilized tomato fruit tissue was extracted with $70 \%$ methanol according to Muir et al. with some modification (Muir et al., 2001). The extraction procedure and LC-MS parameters are well described by Dzakovich et al. (Dzakovich et al., 2016).

Organoleptic sensory panels. Stage-six fruits from Expt. 2 were briefly washed with tap water and wiped dry. Forty-seven panelists (28 female and 19 male between 18 and 71 years of age) were presented with cups containing $\approx 10 \mathrm{~g}$ of diced tomato fruit representing at least six fruits within a treatment. Surveys included both the 9-point hedonic scale (indicating preference) and a 9-point objective scale (indicating magnitude), and panels were conducted according to Dzakovich et al. (Dzakovich et al., 2016). Plain, unsalted crackers and water were provided to all panelists between samples. Personnel hosting the panel had previously completed training modules for ethical human research practices through the Collaborative Institution Training Initiative Program with approval of the local Institutional Review Board.

Statistical analysis. For Expt. 1, data were analyzed as a randomized complete block design and were subjected to analysis of variance and the general linear model procedure of SAS for pooling decisions (v 9.4; SAS Institute, Cary, NC). In addition, means were compared at $\alpha=0.05$ using Tukey's honestly significant difference test. Data from Expt. 1 were compared with outdoor control data using Fisher's protected least significant difference $(\alpha=0.05)$. Data from Expt. 2 were analyzed similarly to data from Expt. 1, although the experiment was analyzed as a completely randomized design. Data from Expt. 2 were not compared with outdoor-grown tomatoes because of the experiment being conducted outside of field season.

\section{Results}

Basic physicochemical properties. In Expt. 1, Brix, $\mathrm{pH}$, titratable acidity, and sugar-to-acid ratio were statistically similar among all greenhouse treatments (Table 1). All greenhouse treatments had statistically lower Brix than outdoor-grown fruits, however. OH-HPS, Hybrid, and ICL-LED treatments had statistically lower $\mathrm{pH}$ than outdoor-grown fruits, but Control fruits were similar. OH-HPS and ICL-LED had statisti- cally lower and higher titratable acidity, respectively, compared with outdoor-grown fruits. All greenhouse treatments except for OH-HPS were statistically lower than outdoor-grown fruits for the sugar-to-acid ratio. In Expt. 2, all basic physicochemical properties were statistically similar among treatments A-E.

Organoleptic sensory panels. In Expt. 2, all absolute and hedonic ratings were statistically similar for all greenhouse treatments. All treatments were above 5.0 for overall acceptance, indicating that fruits from all treatments left a similar, better-than-neutral impression on tasters.

Water-soluble antioxidant compounds. In Expt. 1, ascorbic acid concentration was highest in the ICL-LED-supplemented fruits but not different from Hybrid or OH-HPS treatments (Table 3). None of these treatments were different compared with outdoorgrown fruits except for ICL-LED, which was statistically higher than outdoor-grown fruits. Greenhouse controls had the lowest ascorbic acid concentration and were significantly lower than outdoor-grown fruits. On a fresh weight basis, total ascorbate was statistically similar among all greenhouse treatments but statistically lower than that of outdoor-grown fruits. Phenolics were similar among the four greenhouse treatments and similar to those of outdoor-grown fruits except for ICL-LED, which was statistically higher. Phenolics on a fresh weight basis were statistically similar for all greenhouse treatments. However, the phenolics of Control, OH-HPS, and Hybrid treatments were statistically lower than those of outdoor-grown fruits. Rutin concentration and total rutin were similar for all greenhouse treatments and statistically lower than those of outdoor controls. Kaempferol-3-O-rutinoside concentration and total kaempferol-3-Orutinoside were unaffected by the greenhouse treatments and were statistically similar to those of outdoor-grown fruits, except for Control and
ICL-LED, which were statistically higher than outdoor-grown fruits for kaempferol-3-Orutinoside concentration. In Expt. 2, all watersoluble antioxidant compounds measured in this study were found to be unaffected by the five greenhouse treatments for both concentration and total fruit content.

Carotenoids. All carotenoids measured in Expt. 1, both in terms of concentration and total content, were statistically similar among greenhouse treatments (Table 4). In addition, all greenhouse treatments were significantly lower than outdoor-grown fruits for total content. However, all treatments had statistically similar carotenoid concentrations compared with outdoor-grown fruits except for $\beta$-carotene in the Hybrid treatment. In Expt. 2, all carotenoids were found to be unchanged by the five greenhouse treatments in both concentration and total fruit content.

\section{Discussion}

Although these studies explored the use of light to influence the sensory and chemical characteristics of tomato fruits grown in an industrial production scheme, few measured content attributes were modulated in response to light treatment. Physicochemical metrics such as Brix, $\mathrm{pH}$, and titratable acidity, were found to be nonsignificantly affected by all supplemental light treatments in both Expts. 1 and 2 (Table 1). Before ripening, tomato fruits are photosynthetically active organs that can account for $15 \%$ of photosynthate produced by the entire plant (Carrara et al., 2001). We hypothesized that IC PAR would affect the accumulation of sugars and acids in fruits. However, our findings did not support this hypothesis and paralleled a study where tomato fruit sugars and acids remained unchanged in response to specific wavelengths of light (Gautier et al., 2005 b). Brix was higher in outdoor-grown

Table 4. Major tomato fruit carotenoids as influenced by light treatment or environment.

\begin{tabular}{lccccc}
\hline & $\begin{array}{c}\text { Sample } \\
\text { size }\end{array}$ & $\begin{array}{c}\text { Lycopene } \\
\text { concn } \\
\left(\mathrm{mg} \cdot \mathrm{g}^{-1} \mathrm{DW}\right)^{\mathrm{z}}\end{array}$ & $\begin{array}{c}\text { Lycopene per fruit } \\
(\mathrm{mg} / \text { fruit })^{\mathrm{y}}\end{array}$ & $\begin{array}{c}\beta \text {-Carotene } \\
\text { concn } \\
\left(\mathrm{mg} \cdot \mathrm{g}^{-1} \mathrm{DW}\right)\end{array}$ & $\begin{array}{c}\beta \text {-Carotene } \\
\text { per fruit } \\
(\mathrm{mg} / \text { fruit })\end{array}$ \\
\hline Treatment & $n=9$ & $0.83 \pm 0.05 \mathrm{a}^{\mathrm{x}}$ & $3.88 \pm 0.26 \mathrm{a}^{\mathrm{w}}$ & $0.31 \pm 0.02 \mathrm{a}$ & $1.46 \pm 0.1 \mathrm{a}^{\mathrm{w}}$ \\
$\begin{array}{l}\text { Expt. 1 } \\
\text { Con. }\end{array}$ & $n=9$ & $0.76 \pm 0.08 \mathrm{a}$ & $3.84 \pm 0.38 \mathrm{a}^{\mathrm{w}}$ & $0.27 \pm 0.02 \mathrm{a}$ & $1.37 \pm 0.08 \mathrm{a}^{\mathrm{w}}$ \\
OH-HPS & $n=9$ & $0.7 \pm 0.05 \mathrm{a}$ & $3.93 \pm 0.37 \mathrm{a}^{\mathrm{w}}$ & $0.26 \pm 0.01 \mathrm{a}^{\mathrm{w}}$ & $1.43 \pm 0.11 \mathrm{a}^{\mathrm{w}}$ \\
Hybrid & $n=9$ & $0.83 \pm 0.06 \mathrm{a}$ & $4.64 \pm 0.38 \mathrm{a}^{\mathrm{w}}$ & $0.28 \pm 0.02 \mathrm{a}$ & $1.54 \pm 0.09 \mathrm{a}^{\mathrm{w}}$ \\
ICL-LED & $n=3$ & $0.82 \pm 0.08$ & $8.09 \pm 0.73$ & $0.31 \pm 0.05$ & $3.08 \pm 0.41$ \\
Outdoor & & & & & \\
Expt. 2 & $n=6$ & $0.5 \pm 0.05 \mathrm{a}$ & $4.53 \pm 0.53 \mathrm{a}$ & $0.18 \pm 0.04 \mathrm{a}$ & $1.62 \pm 0.32 \mathrm{a}$ \\
A & $n=6$ & $0.54 \pm 0.05 \mathrm{a}$ & $4.36 \pm 0.47 \mathrm{a}$ & $0.16 \pm 0.01 \mathrm{a}$ & $1.3 \pm 0.09 \mathrm{a}$ \\
B & $n=6$ & $0.6 \pm 0.04 \mathrm{a}$ & $4.27 \pm 0.42 \mathrm{a}$ & $0.23 \pm 0.04 \mathrm{a}$ & $1.53 \pm 0.19 \mathrm{a}$ \\
C & $n=6$ & $0.55 \pm 0.03 \mathrm{a}$ & $4.65 \pm 0.32 \mathrm{a}$ & $0.16 \pm 0.007 \mathrm{a}$ & $1.35 \pm 0.05 \mathrm{a}$ \\
D & $n=6$ & $0.56 \pm 0.06 \mathrm{a}$ & $4.58 \pm 0.59 \mathrm{a}$ & $0.19 \pm 0.02 \mathrm{a}$ & $1.53 \pm 0.12 \mathrm{a}$ \\
E & & & & &
\end{tabular}

${ }^{\mathrm{z}} \mathrm{DW}=$ dry weight

y“"Per fruit" represents concentration corrected for fruit fresh weight.

${ }^{\mathrm{x}}$ Values represent means \pm standard error.

${ }^{\text {w }}$ Significantly different at $P \leq 0.05$ to outdoor controls. Values with different letters within an experiment are statistically different as determined by a Tukey's honestly significant difference test $(\alpha=0.05)$. The supplemental lighting treatments in Expt. 1 were overhead high-pressure sodium (OH-HPS) lamps; intracanopy light-emitting diodes (ICL-LED); hybrid supplemental lighting (OH-HPS + ICL-LED); or unsupplemented controls. In Expt. 2 treatments were A: 0\% blue, $80 \%$ red, and 20\% far red; B: 10\% blue, $90 \%$ red, and $0 \%$ far red; C: unsupplemented control; D: $25 \%$ blue, $60 \%$ red, and $15 \%$ far red; and E: $30 \%$ blue, $70 \%$ red, and $0 \%$ far red. 
tomato fruits that were grown in a cambricloam soil and only received occasional rainfall. Reduced water status and increased soil EC can increase sugar, titratable acids, and carotenoid concentrations in tomato fruits, which may contribute to the differences observed between greenhouse and fieldgrown tomato fruits in Expt. 1 (Kubota et al., 2012; Mitchell et al., 1991; Segura et al., 2009; Wu and Kubota, 2008; Yin et al., 2010). The differences between outdoorgrown and greenhouse tomatoes, as well as the lack of differences among greenhouse treatments, corroborated our sensory data as well as previous findings (Dzakovich et al., 2015).

Tomato flavor is a complex interaction between VOCs, sugars, acids, and previous experiences (Baldwin et al., 2008; Goff and Klee, 2006). Based on our hypotheses regarding how light quality can affect sugars, acids, and VOCs, we were surprised that the supplemental light treatments in Expt. 2 failed to modify (either positively or negatively) the sensory measures of tomato fruits (Table 2). Previous studies have found that sole-source blue, red, and/or far red lighting from LEDs could alter the VOC composition of several horticultural crops, including tomato (Carvalho et al., 2016; Colquhoun et al., 2013). By comparison, our study was conducted in a greenhouse where plants were subjected to a dynamic light environment that shifted throughout the day as well as seasonally. In addition, the fruits measured in Expt. 2 were collected in April, when solar radiation was becoming more dominant in terms of total light received by the plants (Fig. 2). Solar radiation may have masked any effects of supplemental lighting on tomato fruit sensory properties.

In other plant species, environmental conditions, including light quality and quantity, have been shown to modulate the levels of antioxidant compounds measured in our studies (Tables 3 and 4 ) as mediated by the phytochrome and cryptochrome photoreceptor families (Alba et al., 2000; Beggs et al., 1987; Duell-Pfaff and Wellmann, 1982; Müller et al., 2017; Oelmüller and Mohr, 1985). Overexpression of CRYPTOCHROME 2 (CRY2),

Table 5. Calculated phytochrome photoequilibrium from supplemental light treatments in Expt. 2.

\begin{tabular}{ccc}
\hline Treatment & $P_{\mathrm{fr}} / P_{\text {Total }}$ & Red $/$ far red $^{2}$ \\
\hline Expt. 2 & & \\
A & 0.681 & 1.39 \\
B & 0.873 & 100.84 \\
C & n/a & n/a \\
D & 0.684 & 1.46 \\
E & 0.856 & 136.29 \\
\hline
\end{tabular}

${ }^{\mathrm{z}} \operatorname{Red}(600-700 \mathrm{~nm})$, far red $(700-800 \mathrm{~nm})$. Values were calculated at 2-nm increments using the phytochrome photoequilibrium equation by Sager et al. (1988). Supplemental lighting treatments in Expt. 2 were A: $0 \%$ blue, $80 \%$ red, $20 \%$ and far red; B: $10 \%$ blue, $90 \%$ red, and $0 \%$ far red; C: unsupplemented control; D: $25 \%$ blue, $60 \%$ red, and $15 \%$ far red; and E: $30 \%$ blue, $70 \%$ red, and $0 \%$ far red. one of three blue/ultraviolet-A sensing cryptochromes found in tomato plants, greatly increased flavonoids and carotenoids in fruit tissues showing a direct link between blue light perception and phytochemical biosynthesis (Giliberto et al., 2005). Blue light increased carotenoids in lettuce $(\mathrm{Li}$ and Kubota, 2009), kale (Lefsrud et al., 2008), broccoli microgreens (Kopsell and Sams, 2013), and increased lycopene and $\beta$-carotene tomatoes (Gautier et al., 2005b). On the other hand, red light is also critical for carotenoid and flavonoid production in plant tissues ( $\mathrm{Li}$ and Kubota, 2009). Fruit-localized phytochromes were found to mediate carotenogenesis in tomato fruits, and carotenoid content could be enhanced or antagonized by red or far red light, respectively (Alba et al., 2000; Thomas and Jen, 1975). In general, irradiating fruit has been shown to induce production of ascorbic acid in tomato fruits (Gautier et al., 2009). However, we measured only minor perturbations in ascorbic acid, flavonoids, and carotenoids in response to light or environmental treatments. This was most surprising in Expt. 2 where more drastic distinct light treatments were used, although the phytochrome photoequilibrium between treatments was not grossly different (Table 5). However, these measurements were taken at night when solar irradiance was not a factor. Ascorbic acid [dry weight (DW)], phenolics [fresh weight $(\mathrm{FW})$ ], rutin (DW and $\mathrm{FW})$, lycopene, and $\beta$-carotene were statistically lower than outdoor-grown fruits (Tables 3 and 4). Light quality/quantity as well as temperature are among the major drivers of differences between greenhouse and field production (Beggs et al., 1987; Gautier et al., 2005a, 2008, 2009; Massot et al., 2011).

A critically different aspect of our studies compared with those reviewed previously was that they were conducted in a greenhouse with a dynamic light environment. In both Expts. 1 and 2, fruits were harvested at times when solar DLI entering the greenhouse contributed substantially to the total amount of light received by plants (Fig. 2), which may have lessened the effect of supplemental lighting. Moreover, solar radiation is comprised of $30 \%$ to $33 \%$ green light regardless of time of year (Gómez and Mitchell, 2015). Green light has been shown to inhibit the action of cryptochrome, likely through modifying the photoreduction cycle of the flavin adenine dinucleotide chromophore, which is crucial for the perception of light by cryptochrome (Banerjee et al., 2007; Bouly et al., 2007). Green light can also antagonize red and blue light-mediated hypocotyl inhibition and decrease anthocyanins in Arabidopsis leaves (Folta, 2004; Zhang and Folta, 2012). Green light perception is in part mediated by PHOTOTROPIN 1 (PHOT1), CRY1, and CRY2 and is able to modify plant responses to red and blue light (Wang et al., 2013). These findings support the hypothesis that green light present in solar radiation may have nullified potential red, blue, and far red effects of our supplemental lighting treatments.

\section{Conclusion}

Our results indicate that supplemental light quality did not significantly affect the physicochemical or sensory properties of greenhouse-grown tomatoes. Generally speaking, outdoor-grown fruits were statistically different from those grown in a greenhouse production system, and many phytochemicals, such as carotenoids and flavonols, were in higher concentration in outdoor-grown fruits. Although LEDs are being adopted by commercial growers as a way to reduce energy costs, their use in enhancing the sensory or chemical properties of crops may be limited to microgreens, herbs, and leafy greens that are amenable to being grown in sole-source lighting environments. More research is needed to better understand how photobiological processes are regulated in the dynamic light environment of a greenhouse.

\section{Literature Cited}

Alba, R., M-M. Cordonnier-Pratt, and L.H. Pratt. 2000. Fruit-localized phytochromes regulate lycopene accumulation independently of ethylene production in tomato. Plant Physiol. 123:363-370.

Baldwin, E.A., K. Goodner, and A. Plotto. 2008. Interaction of volatiles, sugars, and acids on perception of tomato aroma and flavor descriptors. J. Food Sci. 73:294-307.

Baldwin, E.A., M.O. Nisperos-Carriedo, R. Baker, and J.W. Scott. 1991. Qualitative analysis of flavor parameters in six Florida tomato cultivars (Lycopersicon esculentum Mill). J. Agr. Food Chem. 39:1135-1140.

Banerjee, R., E. Schleicher, S. Meier, R.M. Viana, R. Pokorny, M. Ahmad, R. Bittl, and A. Batschauer. 2007. The signaling state of Arabidopsis cryptochrome 2 contains flavin semiquinone. J. Biol. Chem. 282:14916-14922.

Barta, D.J., T.W. Tibbitts, R.J. Bula, and R.C. Morrow. 1992. Evaluation of light emitting diode characteristics for a space-based plant irradiation source. Adv. Space Res. 12:141-149.

Beggs, C.J., K. Kuhn, R. Böcker, and E. Wellmann. 1987. Phytochrome-induced flavonoid biosynthesis in mustard (Sinapis alba L.) cotyledons. Enzymic control and differential regulation of anthocyanin and quercetin formation. Planta 172:121-126.

Bouly, J.P., E. Schleicher, M. Dionisio-Sese, F. Vandenbussche, D. Van Der Straeten, N. Bakrim, S. Meier, A. Batschauer, P. Galland, R. Bittl, and M. Ahmad. 2007. Cryptochrome blue light photoreceptors are activated through interconversion of flavin redox states. J. Biol. Chem. 282:9383-9391.

Bula, R.J., R.C. Morrow, T.W. Tibbitts, D.J. Barta, R.W. Ignatius, and T.S. Martin. 1991. Lightemitting diodes as a radiation source for plants. HortScience 26:203-205.

Carrara, S., A. Pardossi, G.F. Soldatini, F. Tognoni, and L. Guidi. 2001. Photosynthetic activity of ripening tomato fruit. Photosynthetica 39:7578.

Carvalho, S.D. and K.M. Folta. 2014a. Environmentally modified organisms - Expanding genetic potential with light. Crit. Rev. Plant Sci. 33:486-508

Carvalho, S.D. and K.M. Folta. 2014b. Sequential light programs shape kale (Brassica napus) sprout appearance and alter metabolic and nutrient content. Hort. Res. 1:8. 
Carvalho, S.D., M.L. Schwieterman, C.E. Abrahan, T.A. Colquhoun, and K.M. Folta. 2016. Light quality dependent changes in morphology, antioxidant capacity, and volatile production in sweet basil (Ocimum basilicum). Front. Plant Sci. 7:1328

Ciccone, M.M., F. Cortese, M. Gesualdo, S. Carbonara, A. Zito, G. Ricci, F. De Pascalis, P. Scicchitano, and G. Riccioni. 2013. Dietary intake of carotenoids and their antioxidant and anti-inflammatory effects in cardiovascular care. Mediators Inflamm. 2013:e782137.

Colquhoun, T.A., M.L. Schwieterman, J.L. Gilbert, E.A. Jaworski, K.M. Langer, C.R. Jones, G.V. Rushing, T.M. Hunter, J. Olmstead, D.G. Clark, and K.M. Folta. 2013. Light modulation of volatile organic compounds from petunia flowers and select fruits. Postharvest Biol. Technol. 86:37-44.

Duell-Pfaff, N. and E. Wellmann. 1982. Involvement of phytochrome and a blue light photoreceptor in UV-B induced flavonoid synthesis in parsley (Petroselinum hortense Hoffm.) cell suspension cultures. Planta 156:213217.

Dzakovich, M.P., M.G. Ferruzzi, and C.A. Mitchell. 2016. Manipulating sensory and phytochemical profiles of greenhouse tomatoes using environmentally relevant doses of ultraviolet radiation. J. Agr. Food Chem. 64:6801-6808.

Dzakovich, M.P., C. Gómez, and C.A. Mitchell. 2015. Tomatoes grown with light-emitting diodes or high-pressure sodium supplemental lights have similar fruit-quality attributes. HortScience 50:1498-1502.

Folta, K.M. 2004. Green light stimulates early stem elongation, antagonizing light-mediated growth inhibition. Plant Physiol. 135:1407-1416.

Galvão, V.C. and C. Fankhauser. 2015. Sensing the light environment in plants: Photoreceptors and early signaling steps. Curr. Opin. Neurobiol. 34:46-53.

Gautier, H., V. Diakou-Verdin, C. Bénard, M. Reich, M. Buret, F. Bourgaud, J.L. Poëssel, C. Caris-Veyrat, and M. Génard. 2008. How does tomato quality (sugar, acid, and nutritional quality) vary with ripening stage, temperature, and irradiance? J. Agr. Food Chem. 56:1241-1250.

Gautier, H., C. Massot, R. Stevens, S. Sérino, and M. Génard. 2009. Regulation of tomato fruit ascorbate content is more highly dependent on fruit irradiance than leaf irradiance. Ann. Bot. 103:495-504.

Gautier, H., A. Rocci, M. Buret, D. Grasselly, and M. Causse. 2005a. Fruit load or fruit position alters response to temperature and subsequently cherry tomato quality. J. Sci. Food Agr. 85:1009-1016.

Gautier, H., A. Rocci, M. Buret, D. Grasselly, Y. Dumas, and M. Causse. 2005b. Effect of photoselective filters on the physical and chemical traits of vine-ripened tomato fruits. Can. J. Plant Sci. 85:439-446.

Giliberto, L., G. Perrotta, P. Pallara, J.L. Weller, P.D. Fraser, P.M. Bramley, A. Fiore, M. Tavazza, and G. Giuliano. 2005. Manipulation of the blue light photoreceptor cryptochrome 2 in tomato affects vegetative development, flowering time, and fruit antioxidant content. Plant Physiol. 137:199-208.

Goff, S.A. and H.J. Klee. 2006. Plant volatile compounds: Sensory cues for health and nutritional value? Science 311:815-819.

Gómez, C. and C.A. Mitchell. 2015. Growth responses of tomato seedlings to different spectra of supplemental lighting. HortScience 50:112 118.
González, R., I. Ballester, R. López-Posadas, M.D. Suárez, A. Zarzuelo, O. Martínez-Augustin, and F. Sánchez de Medina. 2011. Effects of flavonoids and other polyphenols on inflammation. Crit. Rev. Food Sci. Nutr. 51:331-362.

González-Vallinas, M., M. González-Castejón, A. Rodríguez-Casado, and A.R. de Molina. 2013. Dietary phytochemicals in cancer prevention and therapy: A complementary approach with promising perspectives. Nutr. Rev. 71:585599.

Gyula, P., E. Schafer, and F. Nagy. 2003. Light perception and signalling in higher plants. Curr. Opin. Plant Biol. 6:446-452.

Jagadeesh, S.L., M.T. Charles, Y. Gariepy, B. Goyette, G.S.V. Raghavan, and C. Vigneault. 2009. Influence of postharvest UV-C hormesis on the bioactive components of tomato during post-treatment handling. Food Bioprocess Technol. 4:1463-1472.

Jones, J.B. 2008. Tomato plant culture: In the field, greenhouse, and home garden. 2nd ed. CRC Press, Boca Raton, FL.

Kauss, T., D. Moynet, J. Rambert, A. Al-Kharrat, S. Brajot, D. Thiolat, R. Ennemany, F. Fawaz, and M.D. Mossalayi. 2008. Rutoside decreases human macrophage-derived inflammatory mediators and improves clinical signs in adjuvantinduced arthritis. Arthritis Res. Ther. 10:R19.

Kopsell, D.A. and C.E. Sams. 2013. Increases in shoot tissue pigments, glucosinolates, and mineral elements in sprouting broccoli after exposure to short-duration blue light from light emitting diodes. J. Amer. Soc. Hort. Sci. 138:31-37.

Kubota, C., M. Kroggel, M. Torabi, K.A. Dietrich, H-J. Kim, J. Fonseca, and C.A. Thomson. 2012. Changes in selected quality attributes of greenhouse tomato fruit as affected by pre- and postharvest environmental conditions in yearround production. HortScience 47:1698-1704.

Külen, O., C. Stushnoff, and D.G. Holm. 2013. Effect of cold storage on total phenolics content, antioxidant activity and vitamin $\mathrm{C}$ level of selected potato clones. J. Sci. Food Agr. 93:2437-2444.

Laing, W.A., M.A. Wright, J. Cooney, and S.M. Bulley. 2007. The missing step of the 1galactose pathway of ascorbate biosynthesis in plants, an 1-galactose guanyltransferase, increases leaf ascorbate content. Proc. Natl. Acad. Sci. USA 104:9534-9539.

Lefsrud, M.G., D.A. Kopsell, and C.E. Sams. 2008. Irradiance from distinct wavelength lightemitting diodes affect secondary metabolites in kale. HortScience 43:2243-2244.

Li, Q. and C. Kubota. 2009. Effects of supplemental light quality on growth and phytochemicals of baby leaf lettuce. Environ. Expt. Bot. 67:5964.

Luthria, D.L., S. Mukhopadhyay, and D.T. Krizek. 2006. Content of total phenolics and phenolic acids in tomato (Lycopersicon esculentum Mill.) fruits as influenced by cultivar and solar UV radiation. J. Food Compos. Anal. 19:771777.

Massot, C., R. Stevens, M. Génard, J-J. Longuenesse, and H. Gautier. 2011. Light affects ascorbate content and ascorbate-related gene expression in tomato leaves more than in fruits. Planta 235:153-163.

Mattson, N.S. and E.D. Harwood. 2012. Effect of light regimen on yield and flavonoid content of warehouse grown aeroponic Eruca sativa. Acta Hort. 956:417-422.

Mitchell, C.A., M.P. Dzakovich, C. Gomez, R. Lopez, J.F. Burr, R. Hernandez, C. Kubota, C.J. Currey, Q. Meng, E.S. Runkle, C.M.
Bourget, R.C. Morrow, and A.J. Both. 2015. Light-emitting diodes in horticulture, p. 1-88. In: J. Janick (ed.). Horticultural Reviews, Vol. 43. Wiley, Hoboken, NJ.

Mitchell, J.P., C. Shennan, S.R. Grattan, and D.M. May. 1991. Tomato fruit yields and quality under water deficit and salinity. J. Amer. Soc. Hort. Sci. 116:215-221.

Mizuno, T., H. Watanabe, and W. Amaki. 2011. Effects of monochromatic light irradiation by LED on the growth and anthocyanin contents in leaves of cabbage seedlings. Acta Hort. 907:179-184.

Morrow, R.C. 2008. LED lighting in horticulture. HortScience 43:1947-1950.

Muir, S.R., G.J. Collins, S. Robinson, S. Hughes, A. Bovy, C.H. Ric De Vos, A.J. van Tunen, and M.E. Verhoeyen. 2001. Overexpression of petunia chalcone isomerase in tomato results in fruit containing increased levels of flavonols. Nat. Biotechnol. 19:470-474.

Müller, N., S. Wenzel, Y. Zou, S. Künzel, S. Sasso, D. Weiß, K. Prager, A. Grossman, T. Kottke, and M. Mittag. 2017. A plant cryptochrome controls key features of the Chlamydomonas circadian clock and its life cycle. Plant Physiol. 174:185-201.

Naderi, G.A., S. Asgary, N. Sarraf-Zadegan, and H. Shirvany. 2003. Anti-oxidant effect of flavonoids on the susceptibility of LDL oxidation. Mol. Cell. Biochem. 246:193-196.

Nagata, M. and I. Yamashita. 1992. Simple method for simultaneous determination of chlorophyll and carotenoids in tomato fruit. Soc. Food Sci. Technol. 39:925-928. (Nippon Shokuhin Kogyo Gakkaishi).

Nelson, J.A. and B. Bugbee. 2014. Economic analysis of greenhouse lighting: Light emitting diodes vs. high intensity discharge fixtures. PLoS One 9:e99010.

Nielsen, S. 2010. Food analysis laboratory manual. 2nd ed. Springer, New York, NY.

Oelmüller, R. and H. Mohr. 1985. Mode of coaction between blue/UV light and light absorbed by phytochrome in light-mediated anthocyanin formation in the milo (Sorghum vulgare Pers.) seedling. Proc. Natl. Acad. Sci. USA 82:6124-6128.

Ordidge, M., P. García-Macías, N.H. Battey, M.H. Gordon, P. Hadley, P. John, J.A. Lovegrove, E. Vysini, and A. Wagstaffe. 2010. Phenolic contents of lettuce, strawberry, raspberry, and blueberry crops cultivated under plastic films varying in ultraviolet transparency. Food Chem. 119:1224-1227.

Raiola, A., M.M. Rigano, R. Calafiore, L. Frusciante, and A. Barone. 2014. Enhancing the healthpromoting effects of tomato fruit for biofortified food. Mediators Inflamm. 2014:139873.

Rizzini, L., J.-J. Favory, C. Cloix, D. Faggionato, A. O'Hara, E. Kaiserli, R. Baumeister, E. Schäfer, F. Nagy, G.I. Jenkins, and R. Ulm. 2011. Perception of UV-B by the Arabidopsis UVR8 protein. Science 332:103-106.

Sager, J.C., W.O. Smith, J.L. Edwards, and K.L. Cyr. 1988. Photosynthetic efficiency and phytochrome photoequilibria determination using spectral data. Trans. ASAE 31:1882-1889.

Segura, M.L., J.I. Contreras, R. Salinas, and M.T. Lao. 2009. Influence of salinity and fertilization level on greenhouse tomato yield and quality. Commun. Soil Sci. Plant Anal. 40:485-497.

Spencer, J.P.E. 2009. The impact of flavonoids on memory: Physiological and molecular considerations. Chem. Soc. Rev. 38:1152-1161.

Stutte, G.W., S. Edney, and T. Skerritt. 2009. Photoregulation of bioprotectant content of red leaf lettuce with light-emitting diodes. HortScience 44:79-82. 
Thomas, R.L. and J.J. Jen. 1975. Red light intensity and carotenoid biosynthesis in ripening tomatoes. J. Food Sci. 40:566-568.

Tieman, D., M. Taylor, N. Schauer, A.R. Fernie, A.D. Hanson, and H.J. Klee. 2006. Tomato aromatic amino acid decarboxylases participate in synthesis of the flavor volatiles 2-phenylethanol and 2-phenylacetaldehyde. Proc. Natl. Acad. Sci. USA 103:8287-8292.
Wang, Y., S.A. Maruhnich, M.H. Mageroy, J.R. Justice, and K.M. Folta. 2013. Phototropin 1 and cryptochrome action in response to green light in combination with other wavelengths. Planta 237:225-237.

Wu, M. and C. Kubota. 2008. Effects of high electrical conductivity of nutrient solution and its application timing on lycopene, chlorophyll and sugar concentrations of hydroponic tomatoes during ripening. Scientia Hort. 116:122-129.
Yin, Y.G., Y. Kobayashi, A. Sanuki, S. Kondo, N. Fukuda, H. Ezura, S. Sugaya, and C. Matsukura. 2010. Salinity induces carbohydrate accumulation and sugar-regulated starch biosynthetic genes in tomato (Solanum lycopersicum L. cv. 'MicroTom') fruits in an ABA- and osmotic stressindependent manner. J. Expt. Bot. 61:563-574.

Zhang, T. and K.M. Folta. 2012. Green light signaling and adaptive response. Plant Signal Behav. 7:75-78. 
Supplemental Table 1. Means and standard errors of fruit fresh weight, fruit water content, and fruit epidermal colorimetric attributes $\left(L^{*}, a^{*}, b^{*}, a^{*} / b^{*}\right)$ in response to experimental treatments.

\begin{tabular}{|c|c|c|c|c|c|c|c|}
\hline Treatment & Sample size & Mass (g) & Water content & $L^{*}$ & $a^{*}$ & $b^{*}$ & $a^{*} / b^{*}$ \\
\hline \multicolumn{8}{|l|}{ Expt. 1 } \\
\hline OH-HPS & $n=9$ & $128.15 \pm 5.02 \mathrm{a}$ & $95.62 \pm 0.25 \mathrm{a}^{\mathrm{z}}$ & $41.81 \pm 0.08 \mathrm{a}$ & $32.05 \pm 0.63 \mathrm{a}^{\mathrm{z}}$ & $24.28 \pm 0.28 \mathrm{a}$ & $1.33 \pm 0.15 \mathrm{a}^{z}$ \\
\hline Hybrid & $n=9$ & $129.01 \pm 8.26 \mathrm{a}$ & $95.6 \pm 0.23 \mathrm{a}^{\mathrm{z}}$ & $40.4 \pm 0.13 \mathrm{a}^{\mathrm{z}}$ & $32.13 \pm 0.92 \mathrm{a}^{\mathrm{z}}$ & $23.6 \pm 0.17 \mathrm{a}$ & $1.37 \pm 0.03 \mathrm{a}^{2}$ \\
\hline Outdoor & $n=3$ & $169.19 \pm 3.82$ & $94.11 \pm 0.06$ & $42.3 \pm 0.003$ & $28.26 \pm 0.46$ & $24.45 \pm 0.23$ & $1.15 \pm 0.01$ \\
\hline \multicolumn{8}{|l|}{ Expt. 2} \\
\hline $\mathrm{A}$ & $n=6$ & $163.91 \pm 5.77 \mathrm{a}$ & $94.5 \pm 0.28 \mathrm{a}$ & $38.57 \pm 0.25 b$ & $25.2 \pm 0.66 \mathrm{a}$ & $19.21 \pm 0.35 \mathrm{c}$ & $1.32 \pm 0.34 \mathrm{a}$ \\
\hline $\mathrm{D}$ & $n=6$ & $157.28 \pm 4.8 \mathrm{ab}$ & $94.59 \pm 0.16 \mathrm{a}$ & $38.7 \pm 0.19 b$ & $26.16 \pm 0.18 \mathrm{a}$ & $19.61 \pm 0.32 b c$ & $1.34 \pm 0.02 \mathrm{a}$ \\
\hline E & $n=6$ & $155.61 \pm 2.2 \mathrm{ab}$ & $94.78 \pm 0.09 \mathrm{a}$ & $40.1 \pm 0.36 \mathrm{a}$ & $26.26 \pm 0.42 \mathrm{a}$ & $21.32 \pm 0.54 \mathrm{a}$ & $1.24 \pm 0.02 \mathrm{a}$ \\
\hline
\end{tabular}

${ }^{\mathrm{z}}$ Significantly different at $P \leq 0.05$ to outdoor controls within individual experiments. Values with different letters within an experiment are statistically differen as determined by a Tukey's honestly significant difference test $(\alpha=0.05)$. The supplemental lighting treatments in Expt. 2 were A: $0 \%$ blue, $80 \%$ red, and $20 \%$ far red; B: $10 \%$ blue, $90 \%$ red, and $0 \%$ far red; C: unsupplemented control; D: $25 \%$ blue, $60 \%$ red, and $15 \%$ far red; and E: $30 \%$ blue, $70 \%$ red, and $0 \%$ far red.

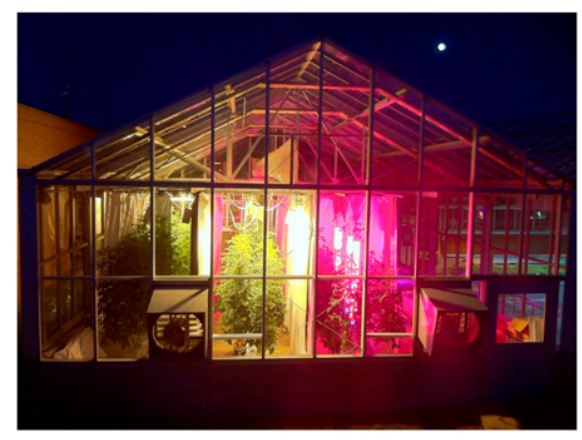

Supplemental Fig. 1. Photograph of greenhouse while Expt. 1 occurred. Tomato plants were arranged in a randomized complete block design and cultured according to industry standards. Treatments and blocks were separated with polyethylene curtains to reduce light pollution from other treatments, and curtains were withdrawn when supplemental lighting was inactive to maximize solar photosynthetically active radiation.

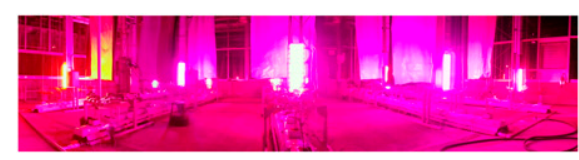

Supplemental Fig. 2. Panoramic photograph of greenhouse setup after transplanting tomato plants used in Expt. 2. Tomato plants were arranged in a full factorial design and cultured according to industry standards. Polyethylene curtains separating rows were withdrawn for the photograph. Towers contained six LED panels that were progressively illuminated as plants reached their full height $(\approx 8 \mathrm{ft})$. Nonilluminated towers served as controls to replicate any effects of shadowing due to tower structure. 